\begin{tabular}{|l|l|l||}
\hline \multicolumn{2}{|c|}{ PublisherInfo } \\
\hline \hline PublisherName & $:$ & BioMed Central \\
\hline \hline PublisherLocation & $:$ & London \\
\hline \hline PublisherImprintName & $:$ & BioMed Central \\
\hline \hline
\end{tabular}

\title{
Prion researcher awarded
}

\begin{tabular}{|l|l|l||}
\hline \multicolumn{2}{|c|}{ ArticleInfo } \\
\hline \hline ArticleID & $:$ & 4868 \\
\hline \hline ArticleDOI & $:$ & $10.1186 /$ gb-spotlight-20031030-01 \\
\hline \hline ArticleCitationID & $:$ & spotlight-20031030-01 \\
\hline \hline ArticleSequenceNumber & $:$ & 220 \\
\hline \hline ArticleCategory & $:$ & Research news \\
\hline \hline ArticleFirstPage & $:$ & 1 \\
\hline \hline ArticleLastPage & $:$ & 3 \\
\hline \hline & & RegistrationDate : 2003-10-30 \\
ArticleHistory & $:$ & OnlineDate $\quad$ 2003-10-30 \\
\hline \hline ArticleCopyright & $:$ & BioMed Central Ltd2003 \\
\hline \hline ArticleGrants & $:$ & \\
\hline \hline ArticleContext & $:$ & 130594411 \\
\hline \hline
\end{tabular}




\section{Ned Stafford}

Email: Hn@europefn.de

Neuropathologist Adriano Aguzzi of University Hospital of Zurich has received this year's international Robert Koch Award for his research into prion diseases.

The Italian-born researcher received the award, which carries a cash prize of $€ 65,000$, during a ceremony in the Reichstag in Berlin. It is given by the Robert Koch Foundation for highly innovative work in infectious diseases that has potential for practical therapeutic applications.

The Koch Foundation's scientific advisory board said it was honoring Aguzzi in recognition of his pioneering discoveries in the field of transmissable spongiform encephalopathies, degenerative brain disorders caused by malformed prion proteins. Well known forms include bovine spongiform encephalopathy ('mad cow disease') and its human equivalent, variant Creutzfeldt-Jakob disease.

Aguzzi, who has researched prion conditions since 1992, described how prions enter the brain and central nervous system, the foundation said. This contributed to the fundamental understanding of the origin of the diseases as well as to prophylactic and therapeutic concepts for the disease.

He has recently succeeded in using an anti-prion protein as an immunization against the disease, Walter Wenninger, a member of the Robert Koch Foundation's board of directors, told us.

Wenninger said of Aguzzi's research: "It is very, very innovative, and it is very close to the patients."

Aguzzi, 42, now back at work in Zurich, told us that awards are much appreciated, but it is making scientific breakthroughs that spikes his adrenaline.

"The Robert Koch Award is wonderful," said Aguzzi, who is director of the Institute of Neuropathology at University Hospital of Zurich. "It was a great pleasure to receive it. But the greatest pleasure is to find something new. That is better than any prize."

Aguzzi said he plans to continue focusing on prion research for at least the next 5 years. "There are plenty of important things to be done still," he said.

About 350 people attended the Reichstag ceremony, which was the first held in Berlin since Robert Koch Foundation Awards were restored after World War II in 1960. Since then, the award ceremony had been held in Bonn.

Another award, the international Robert Koch Gold Medal, a lifetime achievement award, was given during the ceremony to immunologist Tadamitsu Kishimoto, of Japan's University of Osaka. Kishimoto, who was president of Osaka University until August of this year, was honored for his research in the discovery of interleukin 6 and his work in devising possible treatments for inflammatory illnesses.

The Robert Koch Foundation also awarded its annual postdoctoral prizes for research in immunology, virology, and microbiology, each with a cash award of $€ 2500$. Postdoctoral winners included Steffen Backert, of the University of Magdeburg, for his work with Helicobacter pylori; Wolfram Brune, of the 
University of Würzburg, for his work with genetic manipulation of herpes viruses; and Carsten Watzl, of the University of Heidelberg, for his work with natural killer cells.

\section{References}

1. Adriano Aguzzi, [http://www.unizh.ch/pathol/neuropathologie/ptn_aag_cv.html]

2. Winners of the Robert Koch Award since 1970, [http:/www.robert-koch-stiftung.de/ptraeger.html]

3. Perkel JM: Pinning down prion pathogenesis The Scientist, October 15, 2003., [http://www.thescientist.com/news/20031015/06/]

4. Toma T: A possible blood test for prion infection The Scientist, March 1, 2001., [http://www.thescientist.com/news/20010301/02/]

5. Winners of the Robert Koch Gold Medal since 1960, [http://www.robert-koch-stiftung.de/ ptr_gold.html]

6. Osaka University, [http://www.osaka-u.ac.jp/eng/index.html] 